Investigating the effects of explicit and implicit instruction

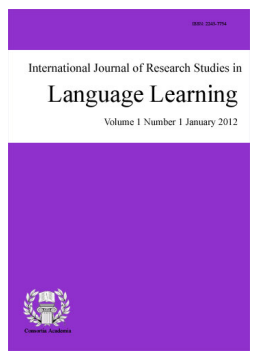

Rezvani, Ehsan

University of Isfahan, Iran (rezvani_ehsan_1982@yahoo.com)

Eslami-Rasekh, Abbass

ISSN: 2243-7754

University of Isfahan, Iran (abbasseslamirasekh@yahoo.com)

Vahid Dastjerdi, Hossein

OPEN ACCESS

University of Isfahan, Iran (h_vahid@yahoo.com)

Received: 22 April 2014

Revised: 23 May 2014

Available Online: 1 June 2014

DOI: $10.5861 /$ ijrsll.2014.799

Accepted: 30 May 2014

Abstract

The present study aimed at investigating the impact of explicit and implicit teaching on the acquisition of the speech acts of requests and suggestions by Iranian EFL learners. To do so, 60 homogenous adult Iranian intermediate EFL learners attending a language institute in Isfahan, Iran, were randomly assigned to two groups: Explicit Group (EG) and Implicit Group (IG). A pre-test was given to the two groups to measure the participants' ability to use requests and suggestions prior to any treatment. Then, both groups were exposed to videos of short conversations including the speech acts under study. The instructional treatment for the EG followed a FonFS paradigm characterized by explicitness and deduction followed by a variety of drills, while the instruction for the IG involved a FonF paradigm characterized by input enhancement and recasts. The results of the post-test, administered after the treatment, indicated that both explicit and implicit teaching exerted a significant effect on the learners' production of requests and suggestions in English. It was also found that there was no statically significant difference between the aforementioned methods of instruction with regard to their effects on learners' pragmatic development.

Keywords: interlanguage pragmatics; explicit instruction; implicit instruction; speech acts 


\section{Investigating the effects of explicit and implicit instruction on Iranian EFL learners' pragmatic development: Speech acts of request and suggestion in focus}

\section{Introduction}

The recent decades have witnessed a surge of interest in interlanguage pragmatics (ILP). In fact, the increasing attention to examining learners' development of pragmatic knowledge from an acquisitional perspective has attracted a large number of researchers to ILP (Kasper \& Dahl, 1999; Bardovi-Harlig, 1999; Kasper \& Rose, 2002; Tateyama, 2001; Trosborg, 2003, among others). Researchers interested in ILP have investigated learners' comprehension and production of a wide range of pragmatic features as well as the processes and factors that influence learners' pragmatic development in both second and foreign language settings (Cohen, 1996; Bardovi-Harlig, 1999; Kasper \& Rose, 2002; Trosborg, 2003; Alcon, 2005, among others). Research findings reveal that in most cases learners' pragmatic competence is incomplete despite enjoying a high level of grammatical competence (Bardovi-Harlig, 2001). Thus, it has been claimed that the instruction of pragmatics is necessary to develop learners' ability to communicate effectively and appropriately, particularly in a foreign language context (Kasper, 2001; Bardovi-Harlig, 2001; Kasper and Rose, 2002). Kasper (2001) points out that contrary to a second language setting, where learners benefit from rich exposure to the target language and ample opportunities to use it for real-life purposes, in foreign language context learners have scarce chances to engage in genuine communication, leading to insufficient pragmatic knowledge. This being so, an urgent need is felt to bring ILP research more directly to SLA research by conducting more acquisition-oriented studies that analyze developmental issues in ILP (Bardovi-Harlig, 2002; Kasper, 1998, 2001); hence, many researchers (e.g. Takahashi, 2001; Martinez-Flor, 2004) have examined the effect of instruction on learners' pragmatic competence in the English as a foreign language (EFL) classroom.

Along the same line of research, an important issue that has received particular attention concerns the investigation of different pedagogical approaches in teaching pragmatics. In this regard, a large number of researchers have focused on comparing the effects of explicit and implicit instruction on second language (L2) pragmatic awareness and development (Fukuya \& zhang, 2002; Fukuya et al., 1998; Rose \& Ng Kwai-fun, 2001; Takahashi, 2001; Martinez-Flor, 2004, among others). In most of these studies, the operationalization of explicit instruction involved the provision of metapragmatic information through description, explanation, and discussion following the Focus on FormS (FonFS) paradigm. On the contrary, implicit instruction was just characterized by a lack of metapragmatic explanations or mere provision of input without any explanations. It can be claimed that a problem with much of the research in the past that has dealt with the effects of explicit and implicit instruction in the realm of pragmatics is insufficient operationalization of these two pedagogical approaches (Kasper \& Rose, 2001). In fact, Kasper (2001) argues that much of previous research has only compared provision of metapragmatic discussions with input-only conditions. It is, then, inevitable that operationalizing explicit and implicit treatments by only considering the provision or lack of metapragmatic explanation is not enough to show whether learners benefit from these instructional conditions. As such, adopting methodologically sound instructional treatments in ILP research by properly operationalizing both explicit and implicit conditions drawing on SLA research was our main concern in this study. Yet another way this study will add to the existing literature is that we focus on the simultaneous teachability of two different pragmatic features in an EFL context where the subjects have very little exposure to the target language. In fact, we hope to add a new dimension to research on interlanguage pragmatics by examining the applicability and effectiveness of input enhancement and recasting in a new EFL context.

Accordingly, this study aimed at investigating the potentially facilitative effects of explicit and implicit instruction on Iranian EFL learners' production of two pragmatic features commonly used in daily conversations, namely the speech acts of requests and suggestions. 


\section{Background of the study}

\subsection{Interlanguage pragmatics (ILP)}

It has been claimed (Kasper, 1989) that the importance of the interlanguage system also entails the acquisition of pragmatic features, leading to a relatively new area of research known as interlanguage pragmatics (ILP). Kasper (1998) contends that ILP seeks to describe and explain learners' development and use of pragmatic knowledge. In another definition, Kasper and Blum-kulka (1993, p. 3) define ILP as "the study of non-native speakers' use and acquisition of linguistic action patterns in a second language". Thus, it can be claimed that the main focus of ILP is on linguistic action or speech acts, which is also the issue addressed in this study.

A few decades ago research in ILP focused mainly on the interaction norms governing speech in different languages and cultures. Mostly, such research aimed at comparing second language (L2) learners' speech act realization with those of native speakers (Kasper, 1989). More recently, however, research findings indicate that there are considerable differences between L2 learners and native speakers with regard to their perception and production of speech acts (Bardovi-Harlig, 2001). Accordingly, the area of pragmatics in the context of SLA has witnessed a surge of interest in studies that examine L2 learners' pragmatic competence. More specifically, recent research has focused on the role of instruction in pragmatic development (for reviews, see Kasper, 2001; Kasper \& Rose, 2002; Martinez-Flor et al., 2003), and it has been found that learners who receive instruction on different aspects of pragmatics have better pragmatic performance (Olshtain \& Cohen, 1990; Takahashi, 2001; Rose \& Ng Kwai-Fun, 2001, Safont, 2005 among others).

\subsection{Previous studies on the speech acts of request and suggestion}

Fukuya et al. (1998) and Fukuya and Clark (2001) were among the first studies that focused on requests. These two studies involved a control group and two experimental groups that received a type of FonFS instruction versus a type of FonF treatment. As for the teaching goals examined, Fukuya et al. (1998) focused on the effect of instruction on learners' ability to use appropriate requests depending on different sociopragmatic factors, while Fukuya and Clark (2001) investigated learners' ability to recognize the appropriate use of mitigators in making requests. Both studies proved to have found inconclusive results due to certain reasons such as brevity of the treatment to prove the effectiveness of implicit instruction, poor operationalization of the implicit techniques employed and the assessment tasks utilized. In another study on the requests, Fukuya and Zhang (2002) examined the effects of instruction with two groups of Chinese EFL learners. This study is one of the very few studies that tried to operationalize the instruction for the implicit treatment group by employing an implicit technique, namely that of recasts.

Fukuya and Zhang (2002) were mainly interested in investigating whether pragmalinguistic recasts were effective for teaching pragmatically appropriate and linguistically accurate requests. After the treatment, which involved fourteen role-plays conducted during seven fifty-minute sessions, results from a written Discourse Completion Task (DCT) revealed that that the recast group outperformed the control group in their use of requests. Focusing on the same speech act, Safont (2001) also examined the effects of instruction on 160 female EFL learners throughout a semester. Falling in the category of teachability studies, the treatment involved description, explanation, discussion, and practice of the requests, and the results of this study showed positive effects of explicit instruction. Similarly, Safont (2003) examining request modification devices reported the benefits of instruction. Moreover, Takahashi (2001), who used the term, input enhancement in a much broader sense than its common operationalizations in the literature, investigated the effects of input enhancement on Japanese EFL learners' acquisition of certain request strategies, and reported that the explicit group outperformed the input enhancement group. Eslami-Rasekh, Eslami-Rasekh, and Fatahi have investigated the effect of explicit metapragmatic instruction on the speech act awareness of requests by advanced Iranian EFL students, and have suggested its positive effects. Vahid Dastjerdi and Rezvani (2010) have also reported the positive effects of 
Rezvani, E., Eslami-Rasekh, A., \& Vahid Dastjerdi, H.

instruction on Iranian EFL learners' acquisition of the speech act of request.

To date, Martinez-Flor (2004) and Martinez-Flor and Fukuya (2005) are the only studies in ILP on the speech act of suggestion. Martinez-Flor (2004) compared the effects of explicit and implicit instruction on 81 Spanish EFL learners' production of suggestions. The results of her study differed from previous research that reported differences between the explicit and implicit teaching approaches. Her findings revealed that both treatments were equally effective in learners' production of appropriate suggestions. Such findings might have been due to her systematic integration of two implicit techniques, namely input enhancement and recasts, with her implicit type of instruction. Similarly, Martinez-Flor and Fukuya (2005) explored the effects of FonF in the pragmatic realm and they reported the equally positive effects of both explicit and implicit instruction on learners' acquisition of suggestions in English. Along the same line of research, Pishghadam and Sharafadini (2011) have reported the benefits of teaching the speech act of suggestion to Iranian EFL learners.

\subsection{Explicit vs. Implicit instruction}

Long (1991) has distinguished between focus on form (FonF) and focus on forms (FonFS). In his view, the latter refers to decontextualized, highly metapragmatic, teacher-centered instruction in which the main objective is to assist learners to accumulate individual language items. The former, however, refers to meaning-focused activities in which learner's attention is drawn to target forms as they arise incidentally in the input. In fact, FonFS employs explicit awareness-raising activates, whereas FonF methods such as input enhancement indirectly and unobtrusively draw learners' attention to target forms.

In this study, explicit instruction was operationalized by the provision of metapragmatic explanations (i.e. metalinguistic and sociopragmatic information on grammatical accuracy and contextual appropriateness of the pragmatic features in question) accompanied by the principles established in the FonFS paradigm such as explicit awareness-raising activities, and practice and production tasks. On the other hand, implicit instruction was characterized by adopting a combination of two implicit language teaching techniques borrowed from the Focus on Form (FonF) paradigm, namely those of input enhancement and recasts.

\subsection{Input enhancement and recasts}

Sharwood Smith (1991, 1993), who introduced 'input enhancement' as a way of directing learners' attention to formal aspects of language information, has noted that input can be made salient by manipulating different aspects of it. Manipulation of input often takes the form of visual input enhancement in which the target forms are made visually salient via such techniques as highlighting, bolding, underlining, color coding, etc. A wide range of research has focused on the effects of input enhancement on the morphosyntactic level (see Doughty \& Williams, 1998). However, research on the implementation of this implicit technique with other aspects of the target language is scarce. Fukuya and Clark (2001) were among the first researchers to operationalize input enhancement at the pragmatic level. Although they found inconclusive results, they claim that integration of this technique to ILP studies may be effective if it were operationalized in a way salient enough for learners to notice. Martinez-Flor (2004) and Martinez-Flor and Fukuya (2005) have also adopted input enhancement in their implicit instructional condition and have reported positive effects of it. Vahid Dastjerdi and Rezvani (2010) have also reported the positive effects of instruction on Iranian EFL learners' acquisition of the speech act of request. Given the scarcity of research in this regard, this study is an attempt to fill the present gap in ILP studies by operationalization and use of input enhancement in a study on two speech acts.

Considering Doughty and Williams's claim (1998) that combined, rather than individual, FonF techniques are more likely to lead to learning, we decided to employ another implicit technique (i.e. recasts) for our implicit group as well. That is, we hope to operationalize the implicit condition by combining input enhancement and recasts.

In a broad sense, recasts are known as the kind of negative feedback that informs learners about what is not 
Investigating the effects of explicit and implicit instruction on Iranian EFL learners' pragmatic development

possible in the target language. Lyster and Ranta (1997, p. 46) contend that "recasts involve the teacher's reformulation of all or part of a student's utterance minus the error." In another definition, Sheen (2006) argues that a recast consists of the teacher's reformulation of all or part of a student's utterance that contains at least one error within the context of a communicative activity in the classroom. The application of recasts in SLA has been the focus of many studies, which have generally reported the benefits of recasts (Mackey, 1995; Lyster, 1998; Long et al., 1998; Leeman, 2003; among others). In fact, Doughty and Williams (1998c) have considered recasts as one of the effective implicit and unobtrusive FonF techniques to draw learners' attention to target language features. One of the only attempts to employ recasts at the pragmatic level was made by Fukuya and Zhang (2002). Their findings indicated that learners in the pragmatic recast condition outperformed those in the control group in their use of the speech act of request. Kasper and Rose (2002) have argued the possibility for the implementation of recasts with a wider range of pragmatic features, and this study hopes to contribute in this regard as well.

\section{Research questions}

This study was an attempt to address the following research questions:

$>$ Does Iranian EFL learners' production of pragmatically appropriate and grammatically accurate requests and suggestions improve significantly after explicit instruction?

$>$ Does Iranian EFL learners' production of pragmatically appropriate and grammatically accurate requests and suggestions improve significantly after implicit instruction?

$>\quad$ Which type of instruction (explicit vs. implicit) exerts a more significant effect in this regard?

\section{Method}

\subsection{Participants}

The participants for this study were randomly chosen from among 90 intermediate Iranian EFL learners, aged 18-25, studying English Translation in the University of Isfahan, Iran. These language learners shared the same first language and were expected not to differ greatly in terms of their English language proficiency. However, in order to make sure in objective terms that the learners were truly homogenous with regard to their English proficiency level, an Oxford Placement Test (Allan, 1992) was given to them. After obtaining the proficiency test results, we chose those participants whose score range fell one standard deviation above and below the mean (i.e. mean \pm 1 ). This being so, 60 participants who met this homogeneity criterion were selected and randomly assigned to the two groups (Explicit and Implicit Group, 30 students each). Moreover, a pre-test was run to ensure us about the participants' homogeneity in terms of their knowledge of speech acts in focus because those participants whose score on the pre-test was 2 standard deviations above and below the mean disqualified for this study.

\subsection{Instructional and pragmatic foci of the study}

The instructional foci of the study consisted of a certain number of head acts (HAs) and downgraders to perform the speech acts of request and suggestion (See Tables $1 \& 2$ ). The selected target forms were divided into two different combinations based on the sociopragmatic factor of status (Brown and Levinson, 1987). On the one hand, Combination 1 focused on certain speech acts regarded as appropriate for situations involving participants with equal status (i.e. student to student in this study). On the other hand, Combination 2 presented the target forms employed in situations with participants of higher status (i.e. student to teacher in this study). In fact, the participants had to perform the requests and suggestions in situations which only varied depending on the status of the speaker compared to that of the addressee. 
Rezvani, E., Eslami-Rasekh, A., \& Vahid Dastjerdi, H.

\section{Table 1}

Target forms for the speech act of request

\begin{tabular}{l|l}
\hline \multicolumn{1}{c|}{ Combination 1 } & \multicolumn{1}{c}{ Combination 2} \\
\hline Status (equal) & Status (higher) \\
Is it OK if I ...? & I was wondering if you could ... \\
Do you mind if I ...? & I'd really appreciate it if you ... \\
Will you please ...? & I'd be grateful if you ... \\
Do you think you can ...? & Would it be OK if I ...? \\
\hline
\end{tabular}

\section{Table 2}

Target forms for the speech act of suggestion

\begin{tabular}{c|l}
\hline \multicolumn{1}{c|}{ Combination 1 } & \multicolumn{1}{c}{ Combination 2 } \\
\hline Status (equal) & \multicolumn{1}{|c}{ Status (higher) } \\
Why don't you ...? & I would probably suggest that ... \\
Have you tried ...? & What is commonly recommended is to ... \\
You'd be better off ... & It would be helpful if you ... \\
You might want to ... & Have you considered ...? \\
Perhaps you should ... & One thing you could do is to ... \\
\hline
\end{tabular}

\subsection{Procedures and treatment}

The experimental design of this study was carried out over a period of around 14 weeks. Homogenous participants, whose English language proficiency had been checked by an Oxford Placement Tests (OPT), were randomly assigned to two groups: the Explicit Group (EG) and the Implicit Group (IG). One week prior to the first treatment session, the participants took the pre-test which consisted of a written production task (an email) designed to elicit the request and suggestion speech acts in different situations and assess the learners' knowledge of these prior to any type of treatment. The pre-test served to ensure us about the participants' homogeneity in terms of their knowledge of speech acts in focus because those participants whose score on the pre-test was 2 standard deviations above and below the mean disqualified for this study. The pre-test contained 12 different situations to which the participants had to respond in written form via email. Then, every group participated in twelve different instructional sessions described in details below. Two days after the last instructional session, the post-test which was parallel in nature to the pre-test was conducted.

The instructional treatment for the EG followed a FonFS paradigm characterized by explicitness and deduction followed by a variety of drills. In every instructional session, learners in this group first watched a video track in which the speech acts in focus occurred in a natural conversation. The video presentation was accompanied by explicit awareness-raising activities and discussions on both pragmalinguistic aspects (i.e. linguistic forms employed to make requests and suggestions), and sociopragmatic ones (i.e. appropriateness issues regarding the status of participants in the video). Moreover, learners in the EG embarked on a variety of production tasks and role-plays. It should be noted that EG learners watched video situations without anything written on the screen and they received scripts of the situations without any words highlighted in bold.

As for the IG, a FonF paradigm was adopted, characterized by input enhancement and recasts. The same video tracks were presented to the learners in the IG. However, they were altered by captions on the video that addressed the sociopragmatic factor involved in the situation. In fact, the captions were to replace the metapragmatic discussions employed for the EG. Moreover, IG learners received scripts in which the target forms (i.e., requests and suggestions in focus) appeared in bold. That is, unlike the EG learners for whom the target forms appeared in plain text-type, IG students were provided with typographical enhancement of the target forms. The purpose of using input enhancement was to indirectly draw learners' attention to forms, function and appropriate usage without embarking on explanation about grammar or metapragmaitc information about appropriate use. In addition, IG learners received recasts while they were engaged in production tasks. 


\subsection{Tests and scoring procedures}

A pre-test and a post-test in the form of a written production task were constructed by the researchers to assess the participants' knowledge of requests and suggestions prior to and after the treatment phase of the study. The pre- and the post-test were conducted in a computer lab by asking the participants to read twelve different scenarios and send emails to real addresses provided to them making a request or a suggestion to either other students (i.e. equal status) or a professor (i.e. higher status). All emails were later checked and printed for analysis. It should be noted that the situations in the pre- and post-test were all different.

Participants' responses to pre- and post-test items (their use of requests and suggestions) were scored considering the type of language used; that is, each linguistically accurate and pragmatically appropriate request was given a single point. Answers which were grammatical but not pragmatically appropriate or vice versa were given half a point, and answers which were neither grammatical nor appropriate were given zero. All the correct answers added up to a total sum of 12 .

To ensure the reliability of the researcher made tests, an alpha Cronbach method was used. The results showed that the two tests enjoyed acceptable reliability indexes for a study of this scope and kind. As for the validity measures, we asked two experts in the field and two native speakers of English to read and examine our tests.

\section{Statistical analyses and results}

\subsection{Research Question 1}

The first research question was to investigate whether explicit instruction exerts a significant influence on Iranian intermediate EFL learners' production of requests and suggestions. This being so, a paired-samples t-test was run. The t-test was intended to compare the obtained mean scores of the participants in EG on the pre- and post-test to indicate the effectiveness of the treatment. The descriptive statistics, along with the results of the t-test for EG, are presented in Tables 3 and 4, respectively.

Table 3

Descriptive statistics for the EG

\begin{tabular}{|c|c|c|c|c|}
\hline & Mean & $\mathrm{N}$ & SD & Std. Error Mean \\
\hline Pair & Pre-test $\quad 6.4312$ & 30 & 1.08321 & .20631 \\
\hline 1 & Post-test 10.8756 & 30 & 1.30019 & .18715 \\
\hline
\end{tabular}

Table 4

Paired-samples t-test results for the $P G$

\begin{tabular}{ccccc}
\hline Mean & SD & t & df & Sig. (2-tailed) \\
\hline Pre/post-test 5.65197 & 1.20271 & 10.509 & 29 & .000 \\
\hline
\end{tabular}

Given the information in Table 3, one can clearly see that the mean score obtained on the post-test (10.8756) is higher than the one obtained on the pre-test (6.4312). However, a paired-samples t-test was run to ensure that the observed difference was significant. Table 4 shows that there is a significant difference in the scores obtained from the pre- and post-test because the probability value is substantially smaller than the specified critical value $(0.000<0.05)$. Accordingly, it can be claimed that explicit instruction was shown to exert a positive effect on the learners' production of the two given speech acts.

\subsection{Research Question 2}

The second research question aimed to shed light on whether implicit instruction has a significant effect on 
Rezvani, E., Eslami-Rasekh, A., \& Vahid Dastjerdi, H.

Iranian intermediate EFL learners' production of requests and suggestions. To answer this question, another paired-samples t-test was conducted. Tables 5 and 6 provide the descriptive statistics, along with the results of the given paired-samples t-test.

Table 5

Descriptive statistics for the $I G$

\begin{tabular}{ccccc}
\hline & Mean & N & SD & Std. Error Mean \\
\hline Pair & Pre-test 6.2981 & 30 & 1.17251 & .22116 \\
1 & Post-test 11.1457 & 30 & 1.17412 & .21852 \\
\hline
\end{tabular}

Table 6

Paired-samples t-test results for the IG

\begin{tabular}{ccccc}
\hline Mean & SD & t & df & Sig. (2-tailed) \\
\hline Pre/post-test 5.02542 & 1.43213 & 10.760 & 29 & .000 \\
\hline
\end{tabular}

On a closer inspection of the mean scores given in Table 5, one can clearly see that the participants in IG gained a higher mean score on the post-test after receiving the treatment (Post-test=11.1457>Pre-test=6.2981). However, the researchers had to go further to find out whether or not the observed difference was significant. Therefore, the results of the t-test were taken into account. It can be concluded from the information presented in Table 6 that there is a significant difference in the performance of the participants on the pre- and post-test. This conclusion can be drawn because the probability value in Table 6 is observed to be 0.000 which is less than the critical value (0.05). In sum, it can be maintained that implicit instruction, operationalized through a combination of input enhancement and recasts, has a positive impact on the Iranian intermediate EFL learners' production of requests and suggestions.

\subsection{Research question 3}

The last research question compared the effectiveness of explicit instruction with that of implicit instruction with regard to the influence these two approaches to teaching exert on the production of certain request and suggestion patterns by Iranian intermediate EFL learners. In fact, this comparison was made to discover whether there is a significant difference between these two approaches in this regard or not. To do so, an independent-samples t-test was run. The results are presented in Table 7 below.

\section{Table 7}

Independent Samples t-test results

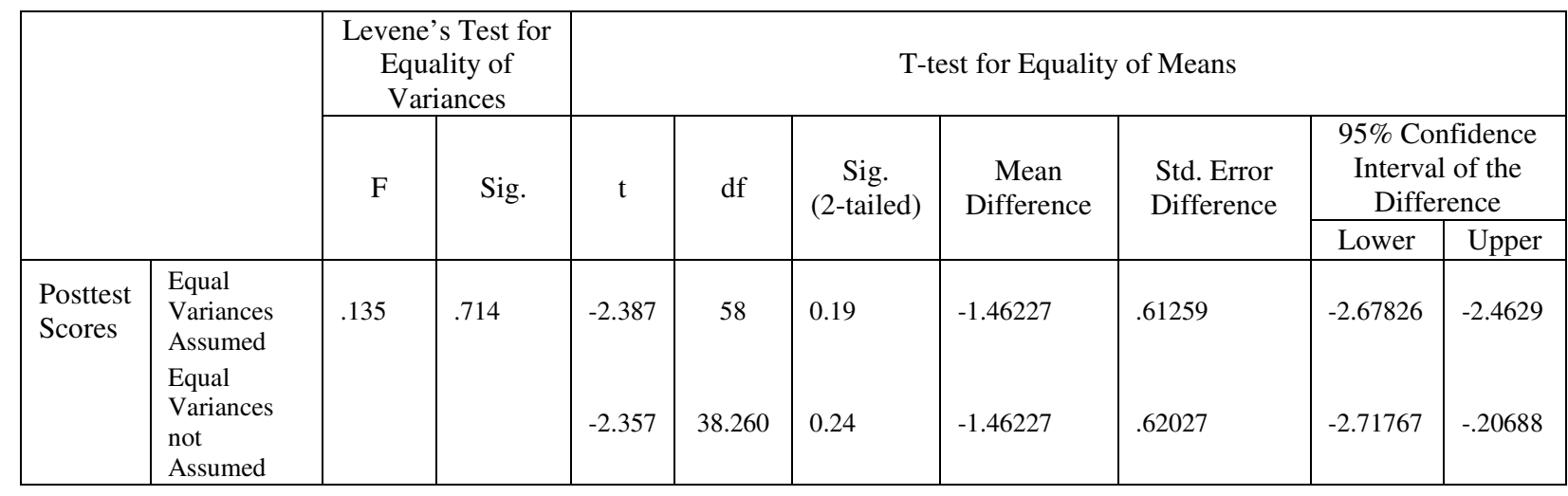

It can be seen in Table 7 that the value listed in the column labeled as Sig. is larger than (0.05). Thus, it can be argued that there was no significant difference between the two groups in terms of the influence they exert on the learners' production of requests and suggestions. 


\section{Discussion}

The present study was an attempt to provide more insights into the effects of instruction on the production of two pragmatic features - speech acts of request and suggestion-in the Iranian EFL setting. Specifically, we investigated the effectiveness of two different teaching methods (i.e. explicit vs. implicit instruction) that were operationalized on the basis of the principles underlying the paradigms of FonFS and FonF (Long, 1996, 1998; Doughty and Williams, 1998). In brief, it was revealed that Iranian EFL learners' production of requests and suggestions improved significantly after both explicit and implicit instruction. In fact, it can be claimed that the present study contributes to previous research that has suggested that instruction does make a difference (Norris \& Ortega, 2000) and in particular to that line of research that has examined the teachability of different pragmatic features (Kasper \& Rose, 2002). Moreover, the findings indicated that explicit and implicit instructions were not significantly different with regard to the influence they exert on the acquisition of the target forms. In this regard, it can be argued that an implicit teaching condition can be effective in developing learners' pragmatic competence if properly implemented. In other words, metapragmatic explanations used with our explicit condition and the systematic combination of the implicit techniques of input enhancement and recasts employed with the implicit condition proved to be equally effective.

The fact that learners who received explicit instruction did significantly better on the post-test suggests that metapragmatic explanations were effective in leading learners to produce linguistically accurate and pragmatically appropriate requests and suggestions. This is in line with previous studies that report the benefits of explicit instruction for L2 pragmatic development (Billmyer, 1990; Bouton, 1994; Rose \& Ng Kwai-fun, 2001; Safont, 2003, 2004, 2005; Takahashi, 2001). More specifically, findings with regard to the first research question in this study lend further support to those studies on the positive effects of explicit instruction which employed explanation and discussion of rules as their approach to provide learners with metapragmatic information (Kubota, 1995; LoCastro, 1997; Trosborg, 2003; Yoshimi, 2001; Wishnoff, 2000; Vahid Dastjerdi \& Rezvani, 2010). The present study, in line with the aforementioned studies, concludes that learners' ability to express more native-like speech acts will improve with explicit instruction, although whether or not that knowledge is retained over time is questionable. Moreover, the significant improvement of the EG in the production of requests and suggestions in this study can be justified considering Bialystok's position (1993) on two cognitive components of language processing — analysis of knowledge and control of processing. Since EG learners received explicit explanation of rules regarding both accuracy and appropriateness of requests and suggestions, their pragmatic knowledge must have been developed in terms of metalinguistic knowledge and the relations between forms and appropriate use.

Moreover, the results demonstrating that the learners who received implicit instruction made significant gains with regard to the production of requests and suggestions concurs with the general findings in earlier studies on the facilitative effects of input enhancement and recasts (Shook, 1994; Doughty, 1991; Leeman et al., 1995; Williams, 1999, Sheen, 2006). It should be noted that studies on the effects of implicit instruction on L2 learners' pragmatic development have produced mixed results. For instance, Fukuya et al. (1998) reported that implicit instruction was not efficient in comparison with explicit instruction. However, the present findings lend further support to those studies which have demonstrated the positive effects of implicit instruction on the acquisition of speech acts (Fukuya \& Clark, 2001; Martinez-Flor, 2004; Alcon, 2005).

Finally, similar to what Martinez-Flor (2004) and Martinez-Flor and Fukuya (2005) have reported, our findings revealed that both treatments were equally effective in learners' production of the pragmatic features in focus. Such findings might have been due to our systematic integration of two implicit techniques, namely input enhancement and recasts, with our implicit type of instruction.

\subsection{Pedagogical implications}

Bearing in mind the findings of the present study, the following pedagogical implication are made. Firstly, 
Rezvani, E., Eslami-Rasekh, A., \& Vahid Dastjerdi, H.

SLA researcher and pragmatists need to realize that there is a close and vital relationship between their areas of research. In other words, ILP, as a hybrid of the two areas of pragmatics and SLA, must play a more central part in today's EFL teaching practice. In fact, materials developers and instructors should integrate pragmatics into their second and foreign language instruction to aid their learners' pragmatic development in second and foreign language settings. Secondly, it should be noted that language practitioner can benefit from input enhancement and recasting as two consciousness-raising techniques that can unobtrusively lead to interlanguage development of their learners. Moreover, it can be claimed a combination of both Fonf and FonFs techniques can lead to better results because EFL learners come to English classes with different learning styles.

\section{References:}

Alcon, E. (2005). Does instruction work for learning pragmatics in the EFL context? System, 33, 417-435. http://dx.doi.org/10.1016/j.system.2005.06.005

Allan, D. (1992). Oxford Placement Test. Oxford: Oxford University Press.

Bardovi-Harlig, K. (1999). Exploring the interlanguage of interlanguage pragmatics: A research agenda for acquisitional pragmatics. Language Learning, 49(4), 677-713. http://dx.doi.org/10.1111/0023-8333.00105

Bardovi-Harlig, K. (2001). Evaluating the empirical evidence: grounds for instruction in pragmatics. In K. R. Rose \& G. Kasper (Eds.), Pragmatics in Language Teaching (pp. 13-32). Cambridge: Cambridge University Press. http://dx.doi.org/10.1017/CBO9781139524797.005

Bardovi-Harlig, K. (2002). Pragmatics and second language acquisition. In R. B. Kaplan (Ed), The Oxford Handbook of Applied Linguistics (pp. 182-192). Oxford: Oxford University Press.

Billmyer, K. (1990). "I like your life style": ESL learners learning how to compliment. Penn Working Papers, 6, 31-48.

Bouton, L. F. (1994). Can NNS skill in implicatures in American English be improved through explicit instruction? In L. F. Bouton (Ed.), Pragmatics and language learning monograph series (Vol. 5, pp. 89-109). Urbana-Champaign: Division of English as an International Language: University of Illinois.

Cohen, A. D. (1996). Developing the ability to perform speech acts. Studies in Second Language Acquisition, 18, 253-267. http://dx.doi.org/10.1017/S027226310001490X

DeKeyser, R. (2003). Implicit and explicit learning. In C. Doughty \& M. Long (Eds.), Handbook of second language acquisition (pp. 313-348). Oxford/New York: Basil Blackwell. http://dx.doi.org/10.1002/9780470756492.ch11

Doughty, C., \& Williams, J. (1998). Pedagogical choices in focus on form. In C. Doughty \& J. Williams (Eds.), Focus on form in classroom second language acquisition (pp. 197-261). Cambridge: Cambridge University Press.

Eslami-Rasekh, Z. (2005). Raising the pragmatic awareness of language learners. ELT Journal, 59(3), 199-208. http://dx.doi.org/10.1093/elt/cci039

Eslami-Rasekh, Z., Eslami-Rasekh, A., \& Fatahi, A. (2004). The Effect of Explicit Metapragmatic Instruction on the Speech Act Awareness of Advanced EFL Students. TESL-EJ, 8(2), 78-90.

Fukuya, Y. J., \& Clark, M. K. (2001). A comparison of input enhancement and explicit instruction of mitigators. In L. F. Bouton (Ed.), Pragmatics and language learning monograph series (Vol. 10, pp. 111-130). Urbana-Champaign: Division of English as an International Language: University of Illinois.

Fukuya, Y., \& Zhang, Y. (2002). Effects of recasts on EFL learners' acquisition of pragmalinguistic conventions of requests. Second Language Studies, 21(1). Working papers of the department of second language studies, University of Hawaii.

Fukuya, Y., Reeve, M., Gisi, J., \& Christianson, M. (1998). Does focus on form work for sociopragmatics? Paper presented at the 12th Annual International Conference on Pragmatics and Language Learning. Urbana, IL.

Kasper, G. (1989). Variation in interlanguage speech act realisation. In S. Gass, C. Madden, D. Preston \& L. Selinker (Eds.), Variation in second language acquisition, Discourse and Pragmatics (pp. 37-58). 
Investigating the effects of explicit and implicit instruction on Iranian EFL learners' pragmatic development

Clevedon, Avon: Multilingual Matters.

Kasper, G. (1998). Interlanguage Pragmatics. In H. Byrnes (Ed.), Learning second and foreign languages (pp.

183-208). New York: Modern Language Association of America.

Kasper, G. (2000). Data collection in pragmatics research. In H. Spencer-Oatey (Ed.), Culturally speaking:

Managing rapport through talk across cultures (pp. 316-341). New York: Continuum.

Kasper, G. (2001). Classroom research on interlanguage pragmatics. In K. R. Rose \& G. Kasper (Eds.),

Pragmatics in language teaching, (pp. 33-60). Cambridge: Cambridge University Press. http://dx.doi.org/10.1017/CBO9781139524797.006

Kasper, G., \& Blum-Kulka, S. (Eds.) (1993). Interlanguage pragmatics. New York: Oxford University Press.

Kasper, G., \& Dahl, M. (1991). Research methods in interlanguage pragmatics. Studies in Second Language Acquisition, 13, 215-247. http://dx.doi.org/10.1017/S0272263100009955

Kasper, G., \& Rose, K.R. (2002). Pragmatic development in a second language. Mahwah, NJ: Blackwell.

Kubota, M. (1995). Teachability of conversational implicatures to Japanese EFL learners. Institute of Research in Language Teaching Bulletin, 9, 35-67.

Leeman, J. (2003). Recasts and second language development: Beyond negative evidence. Studies in Second Language Acquisition, 25, 37-63. http://dx.doi.org/10.1017/S0272263103000020

LoCastro, V. (1997). Pedagogical intervention and pragmatic competence development. Applied Language Learning, 8, 75-109.

LoCastro, V. (1997). Pedagogical intervention and pragmatic competence development. Applied Language Learning, 8, 75-109.

Long, M. H., Inagaki, S., \& Ortega, L. (1998). The role of implicit negative feedback in SLA: Models and recasts in Japanese and Spanish. Modern Language Journal, 82, 357-386. http://dx.doi.org/10.1111/j.1540-4781.1998.tb01213.x

Mackey, A. (1995). Stepping up the pace: Input, interaction, and interlanguage development. An empirical study of acquisition in ESL. Unpublished doctoral dissertation. Australia: The University of Sydney.

Martinez-Flor, A. (2004). The effect of instruction on the development of pragmatic competence in the English as a foreign language context: A study based on suggestions. Doctoral Dissertation. Universitat Jaume I, Castello’n, Spain.

Martinez-Flor, A., \& Fukuya, Y.J. (2005). The effects of instruction on learners' production of appropriate and accurate suggestions. System, 33(3). http://dx.doi.org/10.1016/j.system.2005.06.007

Martínez-Flor, A., Usó-Juan, E. \& Fernández-Guerra, A. (2003). Pragmatic competence and foreign language teaching. Castellón, Spain: Servei de Publicacions de la Universitat Jaume I.

Pishghadam, R. \& Sharafadini, M. (2011). Delving into Speech Act of Suggestion: A Case of Iranian EFL Learners. International Journal of Business and Social Science, 2(16), 152-165.

Rose, K. R., \& Kasper, G. (2001). Pragmatics in language teaching. Cambridge: Cambridge University Press. http://dx.doi.org/10.1017/CBO9781139524797

Rose, K. R., \& Ng, C .K. (2001). Inductive and deductive teaching of compliments and compliment responses. In Rose, K. R., \& Kasper, G. (Eds.), Pragmatics in Language Teaching (pp. 145-170). Cambridge: Cambridge University Press. http://dx.doi.org/10.1017/CBO9781139524797.013

Safont, M.P. (2003). Instructional effects on the use of request acts modification devices by EFL learners. In A. Martínez-Flor, E. Usó, \& A. Fernández (Eds.), Pragmatic Competence and Foreign Language Teaching (pp. 211-232). Spain: Servei de Publicacions de la Universitat Jaume I, Castellón.

Safont, P. (2005). Third language learners: Pragmatic production and awareness. Clevedon, UK: Multilingual Matters.

Sharwood-Smith, M. (1991). Speaking to many minds: On the relevance of different types of language information for the L2 learner. Second Language Research, 7(2), 118-132. http://dx.doi.org/10.1177/026765839100700204

Sharwood-Smith, M. (1993). Input enhancement in instructed SLA: Theoretical bases. Studies in Second Language Acquisition, 15(2), 165-179. http://dx.doi.org/10.1017/S0272263100011943

Sheen, Y. (2006). Exploring the relationship between characteristics of recasts and learner uptake. Language 
Rezvani, E., Eslami-Rasekh, A., \& Vahid Dastjerdi, H.

Teaching Research, 10, 361-392. http://dx.doi.org/10.1191/13621688061r203oa

Takahashi, S. (2001). The role of input enhancement in developing pragmatic competence. In K. R. Rose \& G. Kasper (Eds.), Pragmatics in Language Teaching (pp. 171-199). Cambridge: Cambridge University Press. http://dx.doi.org/10.1017/CBO9781139524797.014

Tateyama, Y. (2001). Explicit and implicit teaching of pragmatics routines: Japanese sumimasen. In K. R. Rose \& G. Kasper (Eds.), Pragmatics in Language Teaching (pp. 200-222). Cambridge: Cambridge University Press. http://dx.doi.org/10.1017/CBO9781139524797.015

Tateyama, Y., Kasper, G., Mui, L.P., Tay, H., \& Thananart, O. (1997). Explicit and implicit teaching of Japanese pragmatics routines. In L. Bouton (Ed.), Pragmatics and Language Learning (pp. 163-177). Division of English as an International Language Intensive English Institute, Urbana, IL: University of Illinois at Urbana- Champaign.

Trosborg, A. (1995). Interlanguage pragmatics: Requests, complaints, and apologies. Berlin: Mouton DeGruyter. http://dx.doi.org/10.1515/9783110885286

Trosborg, A. (2003). The teaching of business pragmatics. In A. Martínez-Flor, E. Usó, \& A. Fernández (Eds.), Pragmatic Competence and Foreign Language Teaching (pp. 247-281). Castellón, Spain: Servei de Publicacions de la Universitat Jaume I.

Vahid Dastjerdi, H., \& Rezvani, E. (2010). The impact of instruction on Iranian intermediate EFL learners production of requests in English. Journal of Language Teaching and Research, 1(6), 782-791. http://dx.doi.org/10.4304/jltr.1.6.782-790

Wildner-Bassett, M. E. (1994). Intercultural pragmatics and proficiency: Polite 'noises' for cultural appropriateness. IRAL, 32(1), 3-17. http://dx.doi.org/10.1515/iral.1994.32.1.3

Wishnoff, J. (2000). Hedging your bets: L2 learners' acquisition of pragmatic devices in academic writing and computer-mediated discourse. Retrieved may 13, 2012, from http://www.hawaii.edu/sls/uhwpesl/on-line cat.html

Yoshimi, D. R. (2001). Explicit instruction and JFL learner's use of interactional discourse markers. In K. R. Rose \& G. Kasper (Eds.), Pragmatics in language teaching (pp. 223-244). Cambridge: Cambridge University Press. http://dx.doi.org/10.1017/CBO9781139524797.016 